\title{
Nutritional, phytochemical and antioxidant evaluation and FT-IR analysis of freeze dried extracts of Ecballium elaterium fruit juice from three localities
}

\author{
Samir FELHI ${ }^{1}$, Hafedh HAJLAOUI ${ }^{2}$, Marwa NCIR ${ }^{3}$, Sana BAKARI ${ }^{1}$, Naourez KTARI ${ }^{4}$, Mongi SAOUDI ${ }^{3}$, \\ Néji GHARSALLAH ${ }^{1}$, Adel KADRI ${ }^{1,5 *}$
}

\begin{abstract}
This study was designed to investigate chemical composition, the total phenolic content, flavonoid content, antioxidant activity and to analyze through FT-IR spectroscopy method the freeze-dried extract of Ecballium elaterium fruit from three different localities. The highest level of phenolic and flavonoid contents was recorded for the fruit juice from the Cap-Bon region, with $106.4 \pm 0.4 \mathrm{mg} \mathrm{GAE} / \mathrm{g}$ and $6.5 \pm 0.2 \mathrm{mg} \mathrm{QE} / \mathrm{g}$, respectively. Antioxidant activity varied in dose-dependent manner with $\mathrm{IC}_{50}$ values for DPPH scavenging of the freeze-dried fruit juice extracts from Cap-Bon, Kef and Sidi Bouzid were 38.6 $\pm 0.2,50.1 \pm 0.7$, and $50.7 \pm 0.2 \mu \mathrm{g} / \mathrm{mL}$, respectively. The results from the FRAP test showed that the freeze-dried extracts of Cap-Bon exhibited potent activity, followed by those from Kef and Sidi Bouzid. Similar trend were revealed for ABTS ${ }^{-+}$test, with the fruit juice extract from Cap-Bon $\left(\mathrm{IC}_{50}=0.6 \pm 0.0 \mathrm{mg} / \mathrm{mL}\right.$ ). Furthermore, a good positive correlation was observed between the total phenols and three assays, especially DPPH. The freeze-dried extracts of fruit juice from Cap-Bon showed strong ability to act as antioxidants and can be considered as promising natural source of bioactive compounds. FT-IR analysis of each freeze-dried extract confirmed its richness on polyphenols and biological active functional groups.
\end{abstract}

Keywords: Ecballium elaterium; chemical composition; antioxidant; FT-IR analysis.

Practical Application: Ecballium elaterium have been used as a natural medicine in Mediterranean and African countries.

\section{Introduction}

Fruits and vegetables are important sources of vitamins, dietary minerals, fibers, and antioxidative compounds. They are a rich source of biologically active compounds, known as phytochemicals, which are an essential and beneficial part of the human diet. Antioxidants are abundant phytochemicals that prevent some of the processes involved in the development of various degenerative disorders and diseases, including cancer and cardiovascular diseases (Denny \& Buttriss, 2007). Recent research has, therefore, become increasingly interested in the search for natural antioxidants from natural origins for use in the treatment and control of several human health disorders and diseases (Ding et al., 2010).

Ecballium elaterium, a wild plant species belonging to the cucurbitacea family, has traditionally been used for various medicinal purposes. The plant, commonly known as squirting cucumber, is widely distributed in the Mediterranean region (Greige-Gerges et al., 2007). It is a perennial, fleshy, rough hairy plant with 30-100 cm long stems and greenish-yellow flowers (Salhab, 2013). It has large, juicy, berry-like, and ovate-oblong fruits that detach themselves explosively at maturity, scattering seeds and juice. E. elaterium is well known as a medicinal plant in Tunisia, frequently consumed in infusion, mixture of fruit or even in aerosol in cases of fever or flu (Bizid et al., 2014). This plant has been widely used in traditional medicine to treat various health disorders and diseases, including constipation, rheumatism, and jaundice (Toker et al., 2003; Attard et al., 2005; Bohlooli et al., 2012), hepatoprotective and proapoptotic effect (El Naggar et al., 2015). The fresh juice fruit has also been applied into the nostrils for the treatment of sinusitis, chronic jaundice and rheumatism (Jaradat et al., 2012; Sargin et al., 2013; Salhab, 2013). The fruit juice from this plant has been reported to be rich in lipids, proteins, sugars, and minerals (Greige-Gerges et al., 2007) and to contain several bioactive compounds, such as triterpenoïdes (cucurbitacins), carbohydrates, tannins, gum and peptides (Attard \& Attard, 2008). The major active compound in this juice, cucurbitacin $B$, has been reported to exhibit attractive anti-ulcerous and anti-inflammatory properties (Agil et al., 1999).

Despite the large flow of data on the promising potential of E. elaterium, to the authors' knowledge, no study has so far investigated the physicochemical composition and antioxidant ability of the fruit juice from E. elaterium. Accordingly, the present study was undertaken to determine the physicochemical composition and total phenolic and flavonoid content of freeze-dried extracts of E. elaterium fruit juices from various 
Tunisian origins. The antioxidant properties of the extracts were also evaluated using 2, 2-diphenyl-1-picrylhydrazyl (DPPH), 2, 2 '-azinobis (3-ethylbenzthiazoline-6-sulphonic acid) (ABTS), and ferric reducing power (FRAP) assays. FT-IR spectrum profiles of various solvent extracts were analyzed to evaluate the IR finger print in different solvent extracts.

\section{Materials and methods}

\subsection{Chemicals and reagents}

DPPH (2,2-Diphenyl-1-picrylhydrazyl), quercetin, trichloroacetic acid, ascorbic acid, ferric chloride $\left(\mathrm{FeCl}_{3}\right), \mathrm{BHT}$ (butylated hydroxytoluene), ferrous sulfate $\left(\mathrm{FeSO}_{4}\right)$, aluminium chloride $\left(\mathrm{AlCl}_{3}\right)$, Folin-Ciocalteu reagent, Trolox (6-hydroxy2,5,7,8-tetramethylchroman-2-carboxylic acid), ABTS (2,2'-azinobis (3-ethylbenzothiazoline-6-sulfonic acid), sodium carbonate $\left(\mathrm{Na}_{2} \mathrm{CO}_{3}\right)$, potassium ferrocyanide $\left(\mathrm{K}_{3} \mathrm{Fe}(\mathrm{CN})_{6}\right)$, potassium persulfate $\left(\mathrm{K}_{2} \mathrm{~S}_{2} \mathrm{O}_{8}\right)$, ethanol, and methanol were purchased from Sigma-Aldrich (USA). All chemicals and solvents were of the analytical grade.

\subsection{Plant materials and extraction}

Fruits juices of E. elaterium were obtained from mature fruits collected in June 2013 from three regions in Tunisia: Cap-Bon, Kef and Sidi Bouzid, at different altitudes (Table 1). After the fruit specimens were authenticated by a recognized botanist, they were deposited at the local herbarium of the biology department of the faculty of Sciences, Sfax, Tunisia. The juices were squeezed from the fruits and then filtered through Whitman paper. A clear juice was obtained, which was then lyophilized using freeze-dryer at a temperature of $-50^{\circ} \mathrm{C}$ and a pressure of about 121 mbar through a lyophilizer lab (CRIST, Alpha 1-2 LD plus, Germany) and then stored at $-20^{\circ} \mathrm{C}$ for further use.

\subsection{Chemical analysis}

The protein concentration in the juice was determined by the Kjeldahl method in accordance with the AOAC method number 984.13 (Association of Official Analytical Chemists, 2000). Crude protein content was estimated by multiplying the total nitrogen content by the factor of 6.25. Crude fat content was determined gravimetrically after the Soxhlet extraction of dried samples with hexane. The moisture and ash contents were evaluated according to the AOAC standard methods 930.15 and 942.05 (Association of Official Analytical Chemists, 1999a, b), respectively. Carbohydrate levels were calculated by subtracting the total sum of protein, fat, ash and moisture from $100 \%$ dry weight sample (Judprasong et al., 2013). The fruit juice energy value (expressed in $\mathrm{kJ}$ ) was estimated by multiplying the percentages of protein, fat and carbohydrate by the factors 16.7, 37.7 and 16.7, respectively (Association of Official Analytical Chemists, 1990).

\subsection{Determination of mineral contents}

Analyses of mineral contents in freeze-dried extracts were carried out using an Atomic Absorption Spectrometer (Perkin Elmer A Analyst 200) according to the method of Association of Official Analytical Chemists (1999c). Sample (1 g) of each extract was dissolved in $1 \mathrm{~mL}$ of $70 \%$ nitric acid. Then it was transformed to a volumetric flask and diluted to $100 \mathrm{~mL}$ with deionised water. The solution was then subjected to analysis. Sample content of each element were determined by comparing absorbance to a standard linear regression curve from standard solutions. The concentration of minerals was calculated and expressed as $\mathrm{mg} / 100 \mathrm{~g}$.

\subsection{Total phenolic content}

Total phenolic content was determined using the method of Li et al. (2007). Two hundred $\mu \mathrm{L}$ of diluted sample were added to $1 \mathrm{~mL}$ of diluted Folin-Ciocalteu reagent (diluted ten times with distilled water). After $4 \mathrm{~min}, 800 \mu \mathrm{L}$ of $\mathrm{Na}_{2} \mathrm{CO}_{3}(75 \mathrm{~g} / \mathrm{L})$ were added. Absorbance was measured at $765 \mathrm{~nm}$ after $2 \mathrm{~h}$ of incubation at room temperature. Gallic acid was used for the standard calibration curve. The results were expressed as $\mathrm{mg}$ of gallic acid equivalents (GAE) per gram of extract (mg GAE/g). All tests were performed in triplicate.

\subsection{Total flavonoid content}

Flavonoid content was determined as described by Bahorun et al. (1996). The quercetin calibration curve was prepared by mixing $1 \mathrm{~mL}$ of samples and quercetin methanolic solution with $1 \mathrm{~mL}$ of aluminium trichloride solution $(2 \%$ in methanol). After $10 \mathrm{~min}$, absorbance was measured at $415 \mathrm{~nm}$. The results were expressed as $\mathrm{mg}$ of quercetin equivalents $(\mathrm{QE})$ per gram of extract $(\mathrm{mg} \mathrm{QE} / \mathrm{g})$. All samples were prepared and analyzed in triplicate.

\subsection{Antioxidant activity assay}

DPPH free radical scavenging activity: The DPPH radical scavenging activity of the extracts was determined according to the method described by Barros et al. (2007), with depends on the reduction of the bleaching of a purple-coloured methanolic solution of the stable radical 2, 2-diphenyl-1-picryl-hydrazyl to a yellow coloured diphenyl-picrylhydrazine. Sample amounts of freeze-dried extract were mixed with $1 \mathrm{~mL}$ of DPPH solution

Table 1. Climatic conditions of Ecballium elaterium at different altitudes in Tunisia.

\begin{tabular}{|c|c|c|c|c|c|c|}
\hline Altitude (growing location) (m) & Longitude (E) & $\begin{array}{l}\text { Latitude } \\
(\mathrm{N})\end{array}$ & $\begin{array}{c}\text { Average rainfall } \\
(\mathrm{mm} / \text { year })\end{array}$ & $\begin{array}{c}\text { Minimum } \\
\text { temperature }\left({ }^{\circ} \mathrm{C}\right)\end{array}$ & $\begin{array}{c}\text { Maximum } \\
\text { temperature }\left({ }^{\circ} \mathrm{C}\right)\end{array}$ & Type of climate \\
\hline 1 (Cap-Bon) & $10^{\circ} 44^{\prime} 15^{\prime \prime}$ & $36^{\circ} 27^{\prime} 21^{\prime \prime}$ & 344.0 & 3.8 & 22.3 & Semi-arid \\
\hline $582(\mathrm{Kef})$ & $8^{\circ} 42^{\prime} 17^{\prime \prime}$ & $36^{\circ} 10^{\prime} 27^{\prime \prime}$ & 361.4 & -2.8 & 41.6 & Semi-arid \\
\hline 354 (Sidi Bouzid) & $9^{\circ} 29^{\prime} 05^{\prime \prime}$ & $35^{\circ} 02^{\prime} 17^{\prime \prime}$ & 288.8 & 13.2 & 25.8 & Arid \\
\hline
\end{tabular}

Source: Infoclimat (2013); data were averaged for the locality in 2013. 
( $2 \mathrm{mg}$ dissolved in $50 \mathrm{~mL}$ methanol). The samples were kept in the dark for $30 \mathrm{~min}$ at room temperature, and absorbance was measured against a blank at $517 \mathrm{~nm}$. DPPH radical scavenging activity was calculated using the following Equation 1:

(\%) Scavenging activity $\left.=\left[\left(\mathrm{A}_{0}-\mathrm{A}_{1}\right) / \mathrm{A}_{0}\right)\right] \times(100)$

Where $A_{0}$ refers to the absorbance of the blank and $A_{1}$ to the absorbance of the sample. The BHT and ascorbic acid were used as positive controls. All tests were performed in triplicate.

ABTS free radical scavenging activity: The spectrophotometric analysis of the $\mathrm{ABTS}^{\cdot+}$ scavenging activity was estimated according to the method of Re et al. (1999). The ABTS stock solution was prepared by mixing a $7 \mathrm{mM}$ of ABTS at $\mathrm{pH} 7.4$ ( $5 \mathrm{mM} \mathrm{NaH}_{2} \mathrm{PO}_{4}, 5 \mathrm{mM} \mathrm{Na}_{2} \mathrm{HPO}_{4}$ and $154 \mathrm{mM} \mathrm{NaCl}$ ) with $2.5 \mathrm{mM}$ potassium persulfate followed by storage in the dark at room temperature for $16 \mathrm{~h}$ before use. On the same day of the analysis, the $\mathrm{ABTS}^{\bullet+}$ solution was diluted with methanol to an absorbance of $0.7 \pm 0.0$ at $734 \mathrm{~nm}$. An amount of $20 \mu \mathrm{L}$ of sample was added to $2 \mathrm{~mL}$ of the diluted $\mathrm{ABTS}^{++}$solution. After 6 min of incubation in the dark, absorbance was measured at $734 \mathrm{~nm}$. Trolox was used as a positive control, and the formula as for DPPH radical scavenging activity was also adopted for the calculation of ABTS radical scavenging activity. All samples were prepared and analyzed in triplicate.

Ferric reducing antioxidant power (FRAP) assay: The reducing power of the extracts was determined according to the method described by Ammar et al. (2015) with some modifications. Briefly, $250 \mu \mathrm{L}$ of each fruit extract at different concentration were mixed with a phosphate buffer $(500 \mu \mathrm{L}, 0.2 \mathrm{M}, \mathrm{pH}$ 6.6) and potassium ferricyanide $(500 \mu \mathrm{L}, 1 \%)$. The mixtures were then incubated at $50{ }^{\circ} \mathrm{C}$ for $20 \mathrm{~min}$. An amount of $500 \mu \mathrm{L}$ of trichloroacetic acid (10\%) was added to each sample, and the mixtures were centrifuged at $1.006 \times \mathrm{g}$ for $10 \mathrm{~min}$. After that, $750 \mu \mathrm{L}$ of the upper layer were mixed with $750 \mu \mathrm{L}$ distilled water and ferric chloride ( $50 \mu \mathrm{L}, 0.1 \%)$. The mixtures were incubated for $10 \mathrm{~min}$ in the dark. Absorbance was measured at $700 \mathrm{~nm}$ against a control that consisted of all the reagents without the test sample. All tests were performed in triplicate.

\subsection{Fourier Transform Infrared Spectroscopy (FT-IR) spectra analysis}

Infrared spectra of freeze-dried extracts from fruit juice of E. elaterium were recorded on a Perkin Elmer FT-IR Spectrum 100 fitted with an ATR accessory. The powdered sample of extract were loaded on the sample chamber of FT-IR spectrophotometer and scanned at room temperature $\left(25 \pm 2{ }^{\circ} \mathrm{C}\right)$ with a scan range from 500 to $4000 \mathrm{~cm}^{-1}$ at a resolution of $2 \mathrm{~cm}^{-1}$.

\subsection{Statistical analysis}

The data represent the means of three measurements \pm standard deviation (SD). Statistical analyses of the data were performed using the SPSS version 17.0 software (SPSS Inc., Chicago, IL, USA). The results were analyzed by one-way analysis of variance (ANOVA) followed by Tukey test for multiple comparisons. Differences were considered significant at $\mathrm{p}<0.05$.

\section{Results and discussion}

\subsection{Chemical analysis}

The results obtained for the compositional content of protein, fat, carbohydrate, energy value, moisture, ash and $\mathrm{pH}$ of E. elaterium fruit juices are shown in Table 2. The fruit was approximately $4 \mathrm{~cm}$ in length and $2 \mathrm{~cm}$ in width. The protein, fat, moisture and ash contents in the juice varied with the region of origin. While the highest amount of protein $(9.2 \pm 0.4 \mathrm{~g} / 100 \mathrm{~g})$ and fat $(3.5 \pm 0.2 \mathrm{~g} / 100 \mathrm{~g})$ contents were recorded for the freeze-dried extracts of Kef and Cap-Bon respectively, the highest levels of moisture $(87.9 \pm 2.2 \mathrm{~g} / 100 \mathrm{~g})$ and ash $(3.8 \pm 0.2 \mathrm{~g} / 100 \mathrm{~g})$ contents was registered for the freeze-dried extracts of Sidi Bouzid and Cap-Bon, respectively. Fruit juice from Cap-Bon showed the highest level of carbohydrate $(3.6 \pm 0.0 \mathrm{~g} / 100 \mathrm{~g})$, followed by fruit juice from Kef $(3.4 \pm 0.0 \mathrm{~g} / 100 \mathrm{~g})$. In addition, the energy values, ranged from $219.1 \pm 0.6$ to $338.7 \pm 0.3 \mathrm{~kJ} / 100 \mathrm{~g}$ indicate a weaker carbohydrate content, with the highest level was obtained for the fruit juice from Kef. Also, we noticed that E. elaterium fruit juices extracted from the three regions exhibited an acidic $\mathrm{pH}$ ranging between 5.1 and 5.5 .

The phytochemical analysis performed on E. elaterium fruit juices from three different regions (Cap-Bon, Sidi Bouzid and Kef) in Tunisia revealed large variations in terms of content (protein, fat, moisture, ash, carbohydrate) and $\mathrm{pH}$ and energy value, which could be attributed to different agro-climatic conditions and soil composition in the regions as well as other physiological and environmental factors.

The presence of high amounts of ash in the three fruit juices, particularly in the variety from Sidi Bouzid, indicated that the fruits had high deposits of mineral elements and justified the presence of adulterants. Moisture and fat were, however, present in adequate amounts to allow for the fresh conditions required for the cure of the disease (Othman et al., 2014) and to constitute a good source of energy, respectively. The results obtained in terms of protein, fat, moisture and ash contents were slightly higher than the ones previously reported by Greige-Gerges et al. (2007). The difference in the chemical composition between the

Table 2. Nutrient composition of Ecballium elaterium fruit juice.

\begin{tabular}{lccccccc}
\hline Growing location & Protein $(\mathrm{g})$ & Fat (g) & Moisture $^{\star}(\mathrm{g})$ & Ash $(\mathrm{g})$ & $\begin{array}{c}\text { Carbohydrate }^{* *} \\
(\mathrm{~g})\end{array}$ & $\begin{array}{c}\text { Energy value } \\
(\mathrm{kJ})\end{array}$ & $\mathrm{pH}$ \\
\hline Cap-Bon & $8.6 \pm 0.3^{\mathrm{b}}$ & $3.5 \pm 0.2^{\mathrm{a}}$ & $80.3 \pm 1.0^{\mathrm{b}}$ & $3.8 \pm 0.2^{\mathrm{a}}$ & $3.6 \pm 0.0^{\mathrm{a}}$ & $336.5 \pm 0.5^{\mathrm{b}}$ & 5.1 \\
Kef & $9.2 \pm 0.4^{\mathrm{a}}$ & $3.3 \pm 0.9^{\mathrm{a}}$ & $81.3 \pm 1.9^{\mathrm{b}}$ & $2.5 \pm 0.2^{\mathrm{b}}$ & $3.4 \pm 0.0^{\mathrm{b}}$ & $338.7 \pm 0.3^{\mathrm{a}}$ & 5.4 \\
Sidi Bouzid & $4.2 \pm 0.5^{\mathrm{c}}$ & $2.6 \pm 0.1^{\mathrm{a}}$ & $87.9 \pm 2.2^{\mathrm{a}}$ & $2.3 \pm 0.1^{\mathrm{c}}$ & $2.8^{\mathrm{c}} \pm 0.0^{\mathrm{c}}$ & $219.1 \pm 0.6^{\mathrm{c}}$ & 5.5 \\
\hline
\end{tabular}

Values are the means of triplicate experiments \pm SD; ${ }^{\star}$ Moisture based on $100 \mathrm{~g}$ fresh weight, all other parameters based on $100 \mathrm{~g}$ dry weight; ${ }^{*}$ Calculated by difference; For each test, different letters in same column followed by a different letter $(\mathrm{a}, \mathrm{b}, \mathrm{c})$ indicate significant difference $(\mathrm{p}<0.05)$ of Ecballium elaterium at three different altitudes. Results are ranked in ascending order; $\mathrm{a}>\mathrm{b}>\mathrm{c}$. 
three extracts of fruit juices of E. elaterium under investigation were statistically significant $(\mathrm{p}<0.05)$.

\subsection{Mineral content of the fruit juices}

The freeze-dried of fruit juices consisted of different minerals at different levels as shown in Table 3. Macroelements (Ca and Mg) and microelements ( $\mathrm{Fe}$ and $\mathrm{Cu}$ ) were analyzed. To the best of our knowledge, this is the first report undertaken the mineral composition of E. elaterium fruit juice. Amongst the macroelements, the highest concentration was observed mainly for the fruit juice from Sidi Bouzid. Mg was the most abundant mineral present in all fruit juices ranging from $12.1 \pm 0.0$ to $32.3 \pm 0.0 \mathrm{mg} / 100 \mathrm{~g}$. The highest concentrations of $\mathrm{Mg}(32.3 \pm 0.0 \mathrm{mg} / 100 \mathrm{~g})$ and $\mathrm{Ca}$ $(12.2 \pm 0.0 \mathrm{mg} / 100 \mathrm{~g})$ were obtained for the freeze-dried extract from Sidi Bouzid. The level of Fe varied with locality with the highest concentration was determined in fruit juices from kef $(1.0 \pm 0.0 \mathrm{mg} / 100 \mathrm{~g})$ followed by Cap-Bon $(0.7 \pm 0.0 \mathrm{mg} / 100 \mathrm{~g})$, while the highest content of $\mathrm{Cu}$ element was found in fruit juice from Cap-Bon $(0.3 \pm 0.0 \mathrm{mg} / 100 \mathrm{~g})$.

Fruits are important contributors of minerals in the diet, and which that the mineral composition and their content of fruits depended on the growing conditions and the stage of maturity (Konczak \& Roulle, 2011). It was considered that calcium and magnesium have a potential relevance in health (Morales-de la Peña et al., 2011) and have essential roles in a variety of body functions including heart, muscle, nerve and immune systems maintenance (Nyanga et al., 2013). The highest content of magnesium in all fruit juices confirmed the antioxidant power of E. elaterium, because this element is a cofactor in almost all phosphorylation reactions and is considered as an indirect antioxidant (Lukaski, 2004).

The variation in the results of chemical and mineral composition of fruit juice extracts of E. elaterium from different locations may have been due to the influence of climatic changes, production factors, maturity state and species and variety of fruit (Halilova \& Yildiz, 2009; Mahdavi et al., 2010).

\subsection{Total phenolic and flavonoid contents}

Phenolics and flavonoids are a major class of bioactive constituents and have beneficial effects on human health. The present study aimed to determine the total content of phenolic and flavonoid in E. elaterium fruit juice expressed in mg of gallic acid equivalents (GAE) per gram of extract (mg GAE/g) and $\mathrm{mg}$ of quercetin equivalents (QE) per gram of extract (mg QE/g), respectively. As summarized in Table 4, the total phenolic and flavonoid contents of E. elaterium fruit juice depended on the zone where it has grown, with the highest content recorded for the fruit juice of the region of Cap-Bon, which displayed $106.4 \pm 0.4 \mathrm{mg} \mathrm{GAE} / \mathrm{g}$ and $6.5 \pm 0.2 \mathrm{mg} \mathrm{QE} / \mathrm{g}$, respectively.

Our investigation indicate the dependence of polyphenolic content on altitudes which is in good agreement with previous study showing that phenolic and flavonoid contents of E. elaterium fruit juices vary significantly with region, geographical conditions and maturity stage (Kondakova et al., 2009). Also, higher phenolic content allowed to lower altitude (Mditshwa et al., 2013; Mphahlele et al., 2014) and lower total flavonoids content may be related to high temperatures by inhibiting biosynthesis and enhancing degradation of flavonoids as observed in fruit harvested in higher and medium altitude with high maximum temperatures.

The results presented in this study showed the richness of the E. elaterium fruit juice from Cap-Bon in terms of phenolic and flavonoid contents, which are the main contributors to the antioxidant activity of fruit juices (Luo et al., 2010; Zakaria et al., 2011; Chai \& Wong, 2012; Schvab et al., 2015). The presence of phenolic and flavonoid is crucial to evaluate antioxidant activity. This is particularly due to their redox properties and chemical structure, which play an important role in absorbing

Table 3. Mineral content of Ecballium elaterium fruit juice.

\begin{tabular}{lcccc}
\hline \multirow{2}{*}{ Growing location } & \multicolumn{4}{c}{ Minerals content $(\mathrm{mg} / 100 \mathrm{~g} \mathrm{dw})$} \\
\cline { 2 - 5 } & Magnesium $(\mathrm{Mg})$ & Calcium $(\mathrm{Ca})$ & Iron $(\mathrm{Fe})$ & $0.7 \pm 0.0^{\mathrm{b}}$ \\
\hline Cap-Bon & $19.4 \pm 0.0^{\mathrm{b}}$ & $5.1 \pm 0.0^{\mathrm{c}}$ & $0.3 \pm 0.0^{\mathrm{a}}$ & \\
Kef & $12.1 \pm 0.0^{\mathrm{c}}$ & $6.2 \pm 0.0^{\mathrm{b}}$ & $1.0 \pm 0.0^{\mathrm{a}}$ & $0.1 \pm 0.0^{\mathrm{a}}$ \\
Sidi Bouzid & $32.3 \pm 0.0^{\mathrm{a}}$ & $12.2 \pm 0.0^{\mathrm{a}}$ & $0.2 \pm 0.0^{\mathrm{c}}$ & $0.2^{\mathrm{a}} \pm 0.0^{\mathrm{a}}$ \\
\hline
\end{tabular}

Values are the means of triplicate experiments \pm SD; For each test, different letters in same column followed by a different letter $(a, b, c)$ indicate significant difference ( $p<0.05)$ of Ecballium elaterium at three different altitudes. Results are ranked in ascending order; $\mathrm{a}>\mathrm{b}>\mathrm{c}$.

Table 4. Total phenolic content, total flavonoid content and DPPH and ABTS scavenging activities of freeze-dried extracts of Ecballium elaterium fruit juices.

\begin{tabular}{lcccc}
\hline \multicolumn{1}{c}{ Growing location } & $\begin{array}{c}\text { Total phenolic } \\
\text { content }(\mathrm{mg} \mathrm{GAE} / \mathrm{g})\end{array}$ & $\begin{array}{c}\text { Total flavonoid content }(\mathrm{mg} \\
\mathrm{QE} / \mathrm{g})\end{array}$ & $\begin{array}{c}\mathrm{IC}_{50} \mathrm{DPPH} \\
(\mu \mathrm{g} / \mathrm{mL})\end{array}$ & $\begin{array}{c}\mathrm{IC}_{50} \mathrm{ABTS} \\
(\mathrm{mg} / \mathrm{mL})\end{array}$ \\
\hline Cap-Bon & $106.4 \pm 0.4^{\mathrm{a}}$ & $6.5^{\mathrm{a}} \pm 0.2^{\mathrm{a}}$ & $38.6 \pm 0.2^{\mathrm{b}}$ & $0.6 \pm 0.0^{\mathrm{c}}$ \\
Kef & $78.7 \pm 0.6^{\mathrm{c}}$ & $0.6 \pm 0.3^{\mathrm{c}}$ & $50.1 \pm 0.7^{\mathrm{a}}$ & $0.8 \pm 0.0^{\mathrm{a}}$ \\
Sidi Bouzid & $86.2 \pm 0.9^{\mathrm{b}}$ & $3.9 \pm 0.1^{\mathrm{b}}$ & $50.7 \pm 0.2^{\mathrm{a}}$ & $0.6 \pm 0.0^{\mathrm{b}}$ \\
Ascorbic acid & - & - & $28.6 \pm 0.6$ & $* .6$ \\
BHT & - & - & $25.3 \pm 0.9$ & $*$ \\
Trolox & - & - & $*$ & $0.4 \pm 0.0$ \\
\hline
\end{tabular}

Results are presented as means \pm SD; Different letters in same column indicate followed by a different letter (a, b, c) significant difference ( $<<0.05)$ of Ecballium elaterium at three different altitudes. Results are ranked in ascending order; $\mathrm{a}>\mathrm{b}>\mathrm{c} ;-$ : not determined; ${ }^{*}$ : not used as standard. 
and neutralizing free radicals, quenching singlet and triplet oxygen, and decomposing peroxides (Čanadanovic-Brunet et al., 2008; Li et al., 2008; Skotti et al., 2014).

\subsection{Antioxidant activities of extracts}

DPPH radical scavenging activity: The antioxidant activity of the E. elaterium fruit juice from the three localities was evaluated by the DPPH assay (based on the principle that a hydrogen donor is an antioxidant) and compared to the standard ascorbic acid and BHT. The results presented in Figure 1 revealed large variation in antioxidant activity, and that this variation was dose-dependent. The antioxidant activities of the fruit juices were expressed in terms of percentage of inhibition and $\mathrm{IC}_{50}$ values (concentration of sample required to scavenge $50 \%$ of free radicals). The findings indicated that the lower the $\mathrm{IC}_{50}$ values were, the higher the antioxidant capacity of the fruit juice extract became. At the highest concentration of $500 \mu \mathrm{g} / \mathrm{mL}$, the fruit juice from the region of Cap-Bon manifested the highest $\mathrm{DPPH} \cdot$ scavenging ability $(85.8 \%)$, followed by the fruit juices of Sidi Bouzid (75.4\%) and Kef (67.0\%), respectively. Radical scavenging activity was also expressed in $\mathrm{IC}_{50}$ values presented in Table 4, and noted to vary according to the region. The best radical scavenging activity was observed for the fruit juice extract from Cap-Bon $(38.6 \pm 0.2 \mu \mathrm{g} / \mathrm{mL})$, followed by the extracts from $\operatorname{Kef}(50.1 \pm 0.7 \mu \mathrm{g} / \mathrm{mL})$ and Sidi Bouzid $(50.7 \pm 0.2 \mu \mathrm{g} / \mathrm{mL})$, respectively. Those values were higher than the ones obtained for $\operatorname{BHT}(25.3 \pm 0.9 \mu \mathrm{g} / \mathrm{mL})$ and ascorbic acid $(28.6 \pm 0.6 \mu \mathrm{g} / \mathrm{mL})$. The differences in the $\mathrm{IC}_{50}$ radical scavenging activity between the freeze-dried extracts of fruit juice of E. elaterium under investigation were statistically significant $(p<0.05)$. In the present study, fruit harvested at lower altitude significantly showed higher antioxidant activity than those harvested at medium and higher altitudes. Higher antioxidant activity has been attributed to higher total polyphenolic compounds present in fruit juice of Cap-Bon region. The difference of fruit juices in the DPPH scavenging activity could be explained by many factors, such as the ripening state of the fruits and environmental differences (Egea et al., 2010; Dou et al., 2013).

Furthermore, the results indicated that the E. elaterium fruit juice extracts from three Tunisian regions had good DPPH scavenging activity, particularly the variety from the Cap-Bon region, which is consistent with the results recorded for polyphenol and flavonoid contents. This, in fact, corroborates the results previously reported in the literature where several bioactive compounds present in this fruit juice, including triterpénoïdes (cucurbitacins), carbohydrates, tannins, gum, peptides and leucoanthocyanins, were reported to enhance antioxidant activity (Attard \& Attard, 2008; Bernard \& Olayinka, 2010). Many researchers have shown that an increase in DPPH inhibition of radicals may be explained by several factors, such as the higher antioxidant power of polyphenols at an intermediate state of oxidation, the increase in reducing sugar and formation of Maillard reaction products, known to have a great antioxidant activity, which is often exerted in a chain-breaking and DPPH type mechanism (Madrau et al., 2009; Herch et al., 2014; İncedayi et al., 2016).

ABTS Free Radical Scavenging Activity: The ABTS radical cation decolorization assay is an excellent tool produced by a reacting ABTS solution with potassium persulfate. It is commonly applied to estimate the total antioxidant activity and to reflect the ability of antioxidant species to donate electrons or hydrogen atoms (Leong \& Shui, 2002). The results obtained for the scavenging ability of the fruit juices with regard to ABTS free radical are expressed as percentages are shown in Figure 2, and the $\mathrm{IC}_{50}$ values are illustrated in Table 4.

The scavenging potential of the fruit juices was noted to correlate well with increasing concentrations, with the greatest $\mathrm{ABTS}^{++}$scavenging activity obtained at $1 \mathrm{mg} / \mathrm{mL}$ for the fruit juice

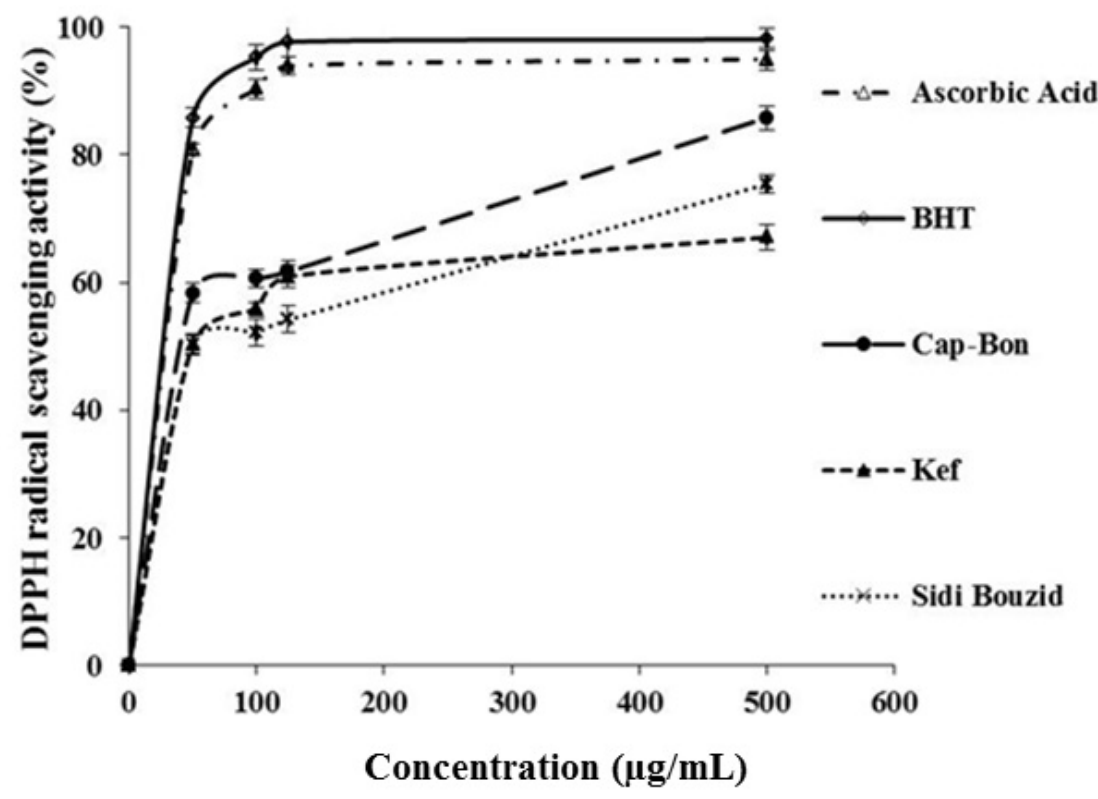

Figure 1. DPPH radical scavenging activity of freeze-dried extracts of Ecballium elaterium fruit juices. 
extract from Cap-Bon (78.9\%), followed by the fruit juice extracts from Sidi Bouzid (70.8\%) and Kef (56.8\%), respectively. The results also indicated that they were lower than the ones recorded for the positive control Trolox (93.4\%). Furthermore, the results revealed that the fruit juice extracts showed variability in terms of scavenging ability, following the same trend observed for $\mathrm{IC}_{50}$ values $(0.6 \pm 0.0 \mathrm{mg} / \mathrm{mL}, 0.6 \pm 0.0 \mathrm{mg} / \mathrm{mL}$ and $0.8 \pm 0.0 \mathrm{mg} / \mathrm{mL}$ for Cap-Bon, Sidi Bouzid and Kef, respectively). This test indicated that the three fruit juice extracts exhibited lower levels of antioxidant activity compared to the positive control Trolox $\left(\mathrm{IC}_{50}=0.4 \pm 0.0 \mathrm{mg} / \mathrm{mL}\right)$ with significant differences $(\mathrm{p}<0.05)$ between all fruits juices.

The scavenging ability of ABTS $^{*+}$ could presumably be attributed to the presence of phytoconstituents in the fruit juices, which can act as electron donors, by reacting with free radicals, and therefore, terminate radical chain reactions (SuárezJiménez et al., 2015). The analysis of ABTS ${ }^{*+}$ radical scavenging activity indicated that the fruit juice extracts contained compounds that have efficient abilities to scavenge free radicals by forming resonance-stabilized phenoxyl radicals. This activity was also noted to vary according to the region of origin, with the highest levels of scavenging activity being recorded for the fruit juice extract from Cap-Bon.

Ferric reducing power assay: The results presented in Figure 3 show the reductive capability of the fruit juice as compared to ascorbic acid. This assay is based on the reduction of $\mathrm{Fe}^{3+}$ ferricyanide complex to the ferrous form $\mathrm{Fe}^{2+}$ by donating an electron to free radicals and converting them into more stable forms (Kadri et al., 2011). An increase in the absorbance at $700 \mathrm{~nm}$ of the reaction mixture indicated increased reducing

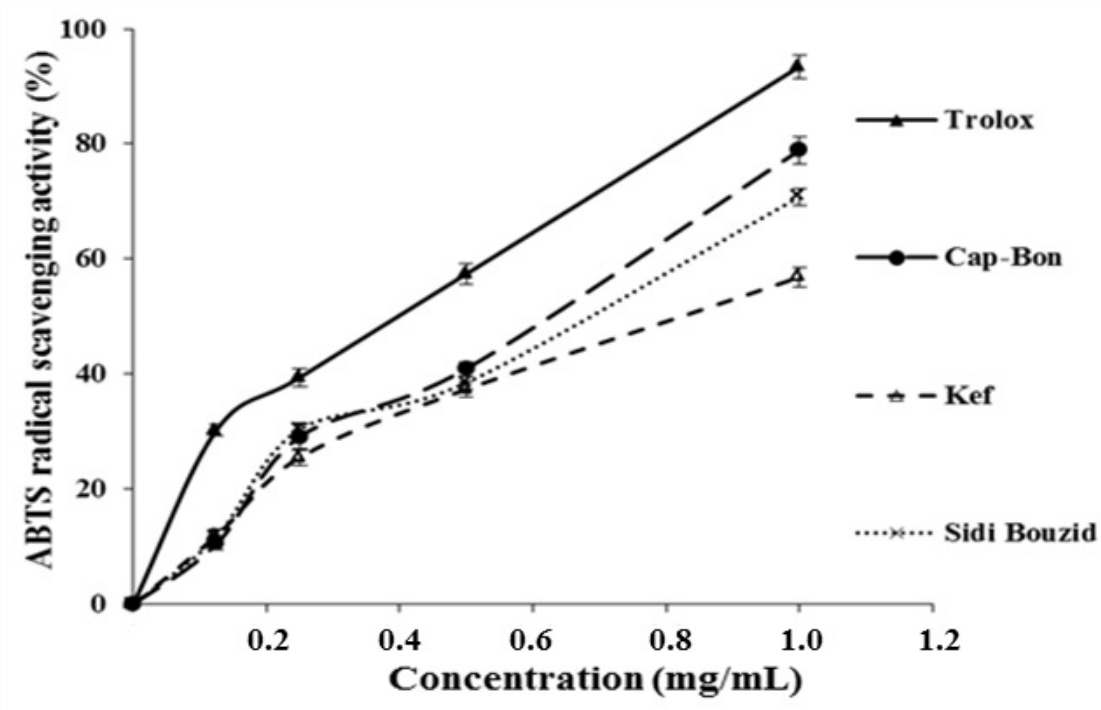

Figure 2. ABTS radical scavenging activity of freeze-dried extracts of Ecballium elaterium fruit juices.

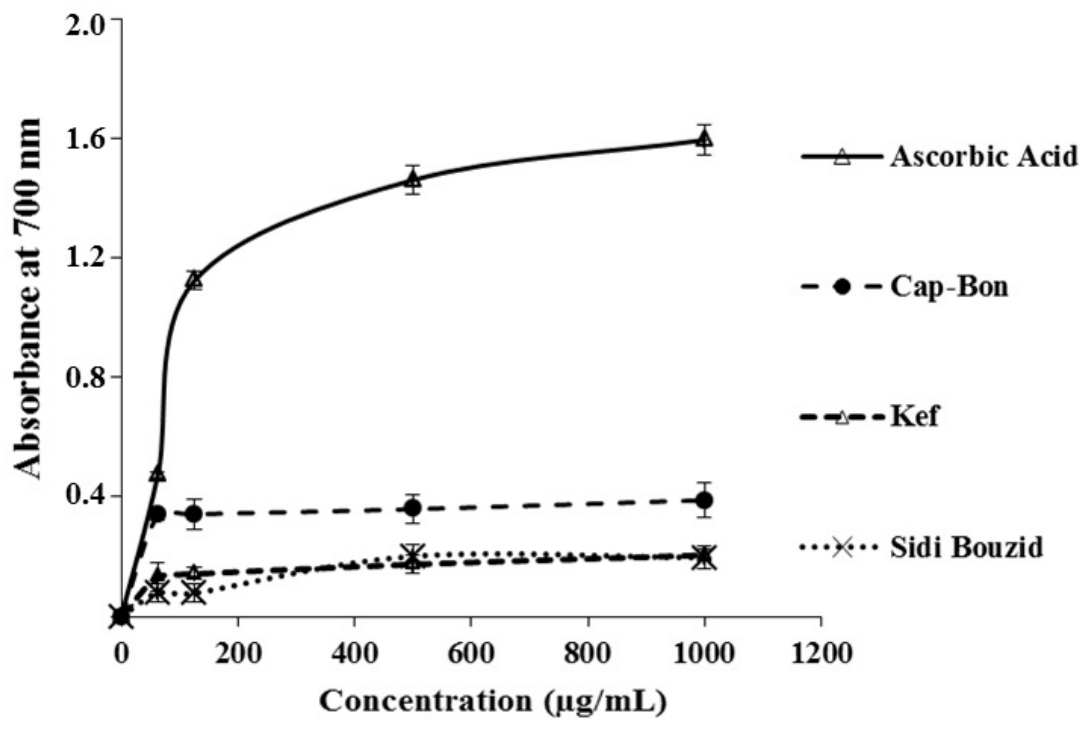

Figure 3. Reducing power effect of freeze-dried extracts of Ecballium elaterium fruit juices. 
power. Among the three localities, the highest antioxidant potential was observed for the fruit juice from Cap-Bon (0.4) as compared to those of Sidi Bouzid and Kef (0.2), which was about four times lower than the positive control (1.6).

As far as reducing power was concerned, the results clearly indicated that the abundance of antioxidant constituents in the fruit juice extracts induced higher rates of reducing power, which varied from one region to another, with the highest value being recorded for the fruit juice extract from Cap-Bon. The results from this assay were similar to those obtained for the DPPH radical scavenging activities. The presence of hydrogen donation and the number and position of hydroxyl groups of phenolic compounds were also noted to affect the antioxidant activity (Leja et al., 2007).

The results from the three assays (DPPH, FRAP and ABTS) also showed significant correlation in terms of the antioxidant capacity of the fruit juices. High correlation coefficients $\left(\mathrm{R}^{2}\right)$ were observed between the total phenolic contents and the DPPH, FRAP and ABTS assays, reaching $0.98,0.95$, and 0.91 respectively, which confirmed that phenolics were the major contributor to antioxidant activity. On the other hand, a good correlation was found between total flavonoid content and DPPH $\left(\mathrm{R}^{2}=0.80\right)$, ABTS $\left(R^{2}=0.99\right)$, and FRAP $\left(R^{2}=0.80\right)$. These strong correlations further confirmed the strong antioxidant potential of phenolic compounds. The antioxidants activities obtained from $\mathrm{DPPH}$, ABTS and FRAP assays were well correlated with each other, with excellent correlation coefficient, and the $\mathrm{R}^{2}$ value for DPPH-ABTS, DPPH-FRAP and FRAP-ABTS were $0.74,0.99$ and 0.74 , respectively. These results implied that the antioxidants in these extracts were capable of reducing oxidants (ferric ions) and scavenging free radicals (DPPH and ABTS).These strong correlations further confirmed the strong antioxidant potential of phenolic compounds. The differences in the antioxidant properties of the different fruit juice extracts could presumably be attributed to the differences in phenolic and flavonoid compositions, which exhibited several biological effects (Canas et al., 2008). Also the concentration of polyphenols may be influenced by the extent of fruit's maturity (Kondakova et al., 2009). The variations of TPC in the present analysis of freeze-dried extracts of E. elaterium fruit juices among different locations could be explained by the influence of different parameters such as temperature and different prevalent environmental factors (Wang \& Zheng, 2001; Miguel et al., 2014).

\subsection{FT-IR spectral analysis}

FT-IR spectral analysis data for the fruit juice extracts revealed the existence of multiple functional groups in the extracts. The spectral features of the extract were shown in Figure 4a-c.
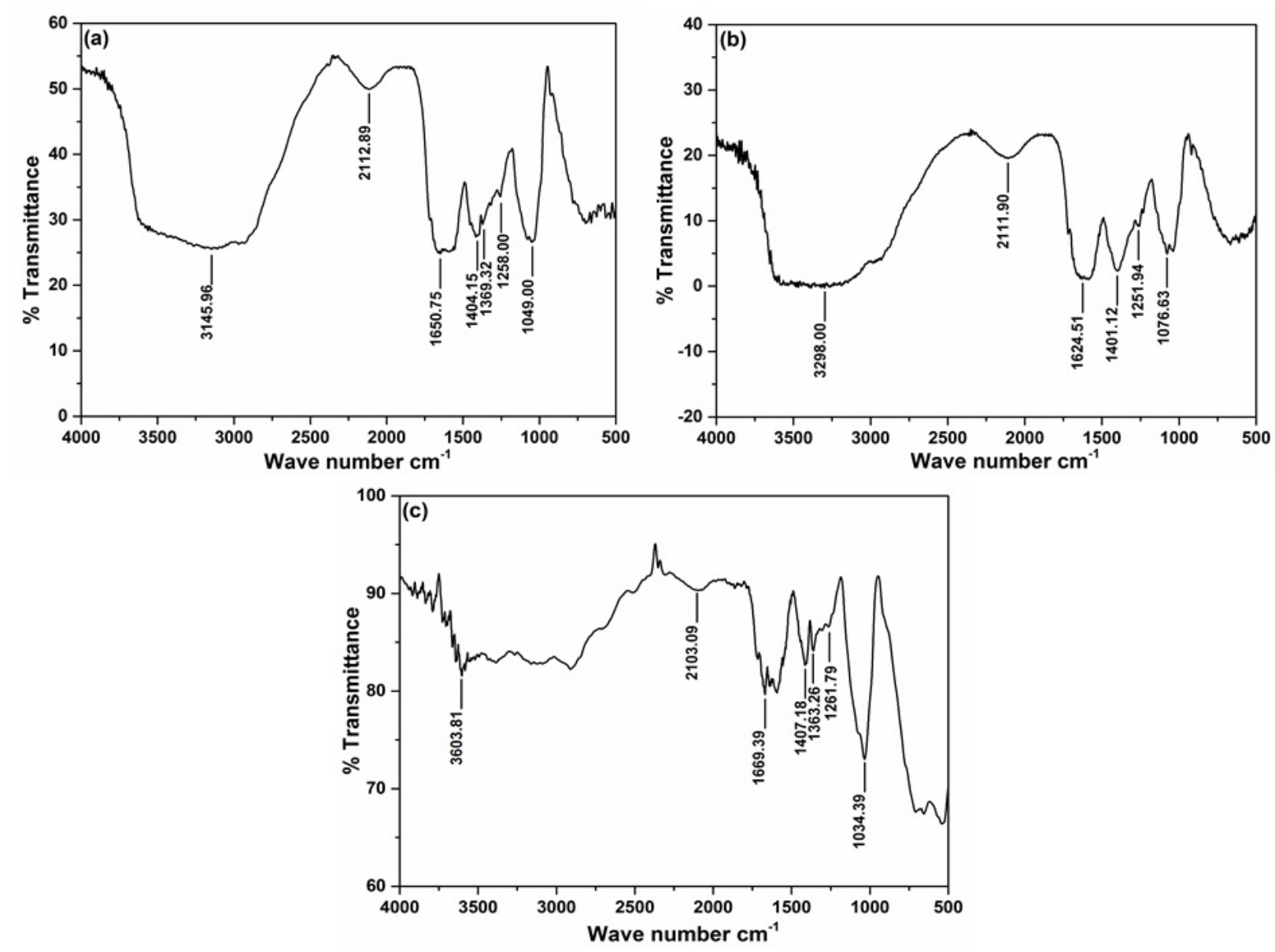

Figure 4. FT-IR spectrum of Freeze-dried extracts of Ecballium elaterium fruit juices from Cap-Bon (a); Kef (b) and Sidi Bouzid (c). 
For all extracts, the very strong absorption bands were observed at $3145.9,3298.0$ and $3603.8 \mathrm{~cm}^{-1}$ of freeze dried extracts of fruit juices from Cap-Bon, Kef and Sidi Bouzid respectively, could be attributed to $\mathrm{N}-\mathrm{H}$ stretching of proteins and $\mathrm{O}-\mathrm{H}$ stretching of carbohydrates and water, which indicate hydroxyl groups existed in all extracts. The bands at $2112.8,2111.9$ and $2103.0 \mathrm{~cm}^{-1}$ of extracts from Cap-Bon, Kef and Sidi Bouzid respectively are due to the $-\mathrm{C} \equiv \mathrm{C}$ group. The bands between the wavenumbers of $1800-750 \mathrm{~cm}^{-1}$ reflected the biochemical compositions, especially the moieties of carbohydrate, lipid, protein and polyphenols in plant. The absorptions around 1650.7, 1624.5 and $1669.3 \mathrm{~cm}^{-1}$ could be assigned to ring $\mathrm{C}-\mathrm{C}$ stretch of phenyl ( $\mathrm{Lu}$ et al., 2011), which is present at high levels in the polyphenolic components of E. elaterium fruit juices. Absorptions peak at $1404.1,1401.1$ and $1407.1 \mathrm{~cm}^{-1}$ for extracts from Cap-Bon, Kef and Sidi Bouzid respectively, corresponding to $\mathrm{CH}_{3}$ asymmetric deformation (Agarwal et al., 2006). Only for extracts from Cap-Bon and Sidi Bouzid, the presence of peak at 1369.3 and $1363.2 \mathrm{~cm}^{-1}$ respectively, is due to the in-plane $\mathrm{C}-\mathrm{O}$ stretching vibration combined with the ring stretch of phenyl (Schulz \& Baranska, 2007). The minor bands obtained at $1258.0,1251.9$ and $1261.7 \mathrm{~cm}^{-1}$ from Cap-Bon, Kef and Sidi Bouzid respectively, were ascribed to $\mathrm{O}-\mathrm{H}(-\mathrm{COOH})$ variable angle vibration (Zhao et al., 2014). The wavenumber region between 1200 and $950 \mathrm{~cm}^{-1}$ contains functional groups mainly from carbohydrates, while absorptions peak at $1049.0,1076.6$ and $1034.3 \mathrm{~cm}^{-1}$ are attributed of $-\mathrm{CH}_{2} \mathrm{OH}$ groups of carbohydrates (Lu et al., 2011). The various functional groups observed in fruit juice extracts of E. elaterium reflected the biochemical compositions, especially the phenolic compounds, carboxylic acids, alcohols, carbohydrates, and proteins in the plant, responsible for several medicinal properties and biological activities which is confirmed by our investigation in chemical composition. The presence of phytochemicals carrying hydrogen functional group - $\mathrm{OH}$ bonded found that the hydroxyl functionality is an integral part of most of phenolic phytochemicals such as polyphenols and flavonoids to provide a relative ranking of extracts in term of antioxidant activity.

Therefore, the presence of characteristic functional groups that are responsible for various medicinal properties may be influence considerably the biological properties and contribute significantly to their solubility, partition coefficient, stereochemistry and inherent acid-base properties (Knittel \& Zavod, 2008). From the results obtained in the present study, it could be concluded that the E. elaterium fruit juice extracts in relationship with their phytoconstituents (total phenolic and flavonoid contents,...) may act as source of therapeutic agent. The diversity of functional groups observed probably indicate the presence of carbohydrates, carotenoid, glycogen, amino acids, amides, starch, calotropin, calotropogenin, phosphates, lipids, glycogen and cellulose. The richness of E. elaterium fruit juice extracts - $\mathrm{OH}$ group enhances its ability for forming hydrogen bonding capacity and confirmed therefore, the higher potential of its antioxidant activity (Diaz et al., 2012).

\section{Conclusions}

In conclusion, the present study is the first to report on the chemical composition and antioxidant activity of freeze-dried extracts from fruit juice of E. elaterium growing in Tunisia.
The findings revealed variability in chemical composition, high phenolic and flavonoid contents, and potent antioxidant activity, which depended on the area of origin, with relatively advanced properties for the freeze-dried extracts from Cap-Bon. A strong positive correlation was observed between the total phenolic content and values of antioxidant activity. Considering the promising properties and attributes of E. elaterium fruit juice, further studies, some of which are currently underway in our laboratories, are needed to to isolate investigate the active compounds responsible for antioxidant activity and evaluate their potential use as supplements in functional foods and pharmaceutical formulations. The various functional groups observed in the different extracts probably confirmed by FT-IR analysis indicate the richness of E. elaterium fruit juice in polyphenols.

\section{References}

Agarwal, R., Tandon, P., \& Gupta, V. D. (2006). Phonon dispersion in poly (dimethylsilane). Journal of Organometallic Chemistry, 691(13), 2902-2908. http://dx.doi.org/10.1016/j.jorganchem.2006.02.032.

Agil, A., Miro, M., Jimenez, J., Aneiros, J., Caracuel, M. D., GarciaGranados, A., \& Navarro, M. C. (1999). Isolation of ani-hepatotoxic principle from the juice of Ecballium elaterium. Planta Medica, 65(7), 673-675. http://dx.doi.org/10.1055/s-2006-960847. PMid:15609462.

Ammar, I., Ennouri, M., \& Attia, H. (2015). Phenolic content and antioxidant activity of cactus (Opuntia ficus-indica L.) flowers are modified according to the extraction method. Industrial Crops and Products, 64, 97-104. http://dx.doi.org/10.1016/j.indcrop.2014.11.030.

Association of Official Analytical Chemists - AOAC. (1990). Official Methods of analysis of the Association of Official Analytical Chemists. Arlington: AOAC.

Association of Official Analytical Chemists - AOAC. (1999a). Official methods of analysis of the Association of Official Analytical Chemists: method 430.15 (16th ed.). Washington: AOAC.

Association of Official Analytical Chemists - AOAC. (1999b). Official methods of analysis of of the Association of Official Analytical Chemists: method 942.05 (16th ed.). Washington: AOAC.

Association of Official Analytical Chemists - AOAC. (1999c). Official methods of analysis of of the Association of Official Analytical Chemists (16th ed.). Washington: AOAC.

Association of Official Analytical Chemists - AOAC. (2000). Official methods of analysis of of the Association of Official Analytical Chemists: method 984.13 (17th ed.). Washington: AOAC.

Attard, E., \& Attard, H. (2008). Antitrypsin activity of extracts from Ecballium elaterium seeds. Fitoterapia, 79(3), 226-228. http://dx.doi. org/10.1016/j.fitote.2007.11.020. PMid:18331783.

Attard, E., Brincat, M. P., \& Cuschieri, A. (2005). Immunomodulatory activity of cucurbitacin $\mathrm{E}$ isolated from Ecballium elaterium. Fitoterapia, 76(5), 439-441. http://dx.doi.org/10.1016/j.fitote.2005.02.007. PMid:15908139.

Bahorun, T., Grinier, B., Trotin, F., Brunet, G., Pin, T., Luncky, M., Vasseur, J., Cazin, M., Cazin, C., \& Pinkas, M. (1996). Oxygen species scavenging activity of phenolic extracts from Hawthorn fresh plant organs and pharmaceutical preparations. Arzneimittel-Forschung, 46(11), 1086-1089. PMid:8955870.

Barros, L., Baptista, P., \& Ferreira, I. C. F. R. (2007). Effect of Lactarius piperatus fruiting body maturity stage on antioxidant activity measured by several biochemical assays. Food and Chemical Toxicology, 45(9), 1731-1737. http://dx.doi.org/10.1016/j.fct.2007.03.006. PMid:17459553. 
Bernard, S. A., \& Olayinka, O. A. (2010). Search for a novel antioxidant, anti-inflammatory/analgesic or anti-proliferative drug: Cucurbitacins hold the ace. Journal of Medicinal Plants Research, 4(25), 2821-2826. Retrieved from http://www.academicjournals.org/JMPR/PDF/ pdf2010/29Dec/Saba\%20and\%20Oridupa.pdf

Bizid, S., Sabbah, M., Msakni, I., Ben Slimene, B., Mohamed, G., Bouali, R., Ben Abdallah, H., \& Abdelli, N. (2014). Cholestatic hepatitis due to Ecballium elaterium ingestion. Clinics and Research in Hepatology and Gastroenterology, 39(5), e61-e63. http://dx.doi.org/10.1016/j. clinre.2014.11.004. PMid:25573494.

Bohlooli, S., Jafari, N., \& Jahed, S. (2012). Cytotoxic effect of freezedried extract of Ecballium elaterium fruit on gastric adenocarcinoma (AGS) and esophageal squamous cell carcinoma (KYSE30) cell lines. Journal of Gastrointestinal Cancer, 43(4), 579-583. http://dx.doi. org/10.1007/s12029-012-9383-4. PMid:22415321.

Čanadanovic-Brunet, J., Ćetkovic, G., Djilas, S., Tumbas, V., Bogdanovic, G., Mandic, A., Markov, S., Cvetkovic, D., \& Čanadanovic, V. (2008). Radical scavenging, antibacterial, and antiproliferative activities of Melissa officinalis L. extracts. Journal of Medicinal Food, 11(1), 133-143. http://dx.doi.org/10.1089/jmf.2007.580. PMid:18361749.

Canas, S., Casanova, V., \& Belchior, A. P. (2008). Antioxidant activity and phenolic content of Portuguese wine aged brandies. Journal of Food Composition and Analysis, 21(8), 626-633. http://dx.doi. org/10.1016/j.jfca.2008.07.001.

Chai, T. T., \& Wong, F. C. (2012). Whole-plant profiling of total phenolic and flavonoid contents, antioxidant capacity and nitric oxide scavenging capacity of Turnera subulata. Journal of Medicinal Plants Research, 6(9), 1730-1735. Retrieved from http://www. academicjournals.org/JMPR

Denny, A., \& Buttriss, J. (2007). Plant foods and health: focus on plant bioactives (Synthesis Repor, No. 4). Norwich: Institute of Food Research.

Diaz, P., Jeong, S. C., Lee, S., Khoo, C., \& Koyyalamudi, S. R. (2012). Antioxidant and anti-inflammatory activities of selected medicinal plants and fungi containing phenolic and flavonoid compounds. Chinese Medicine, 7(1), 1-9. http://dx.doi.org/10.1186/1749-8546-7-26

Ding, X., Tang, J., Cao, M., Guo, C. X., Zhang, X., Zhong, J., Zhang, J., Sun, Q., Feng, S., Yang, Z. R., \& Zhao, J. (2010). Structure elucidation and antioxidant activity of a novel polysaccharide isolated from Tricholoma matsutake. International Journal of Biological Macromolecules, 47(2), 271-275. http://dx.doi.org/10.1016/j.ijbiomac.2010.04.010. PMid:20430053.

Dou, D., Leng, P., Li, Y., Zeng, Y., \& Sun, Y. (2013). Comparative study of antioxidant compounds and antiradical properties of the fruit extracts from three varieties of Crataegus pinnatifida. Journal of Food Science and Technology, 52(1), 430-436. http://dx.doi.org/10.1007/ s13197-013-0954-6.

Egea, I., Sanchez-Bel, P., Romojaro, F., \& Pretel, M. T. (2010). Six edible wild fruits as potential antioxidant additives or nutritional supplements. Plant Foods for Human Nutrition (Dordrecht, Netherlands), 65(2), 121 129. http://dx.doi.org/10.1007/s11130-010-0159-3. PMid:20198440.

El Naggar, M. B., Chalupova, M., Prazanova, G., Parak, T., Švajdlenka, E., Žemlicka, M., \& Suchy, P. (2015). Hepatoprotective and proapoptotic effect of Ecballium elaterium on $\mathrm{CCl}_{4}$-induced hepatotoxicity in rats. Asian Pacific Journal of Tropical Medicine, 8(7), 526-531. http:// dx.doi.org/10.1016/j.apjtm.2015.06.012. PMid:26276282.

Greige-Gerges, H., Khalil, R. A., Mansour, E. A., Magdalou, J., Chahine, R., \& Ouaini, N. (2007). Cucurbitacins from Ecballium elaterium Juice Increase the Binding of Bilirubin and Ibuprofen to Albumin in Human Plasma. Chemico-Biological Interactions, 169(1), 53-62. http://dx.doi.org/10.1016/j.cbi.2007.05.003. PMid:17601519.
Halilova, H., \& Yildiz, N. (2009). Does climate change have an effect on proline accumulation in pomegranate (Punica granatum L.) fruits? Scientific Research and Essays, 4(12), 1543-1546.

Herch, W., Kallel, H., \& Boukhchina, S. (2014). Physicochemical properties and antioxidant activity of Tunisian date palm (Phoenix dactylifera L.) oil as affected by different extraction methods. Food Science and Technology (Campinas.), 34(3), 464-470. http://dx.doi. org/10.1590/1678-457x.6360.

İncedayi, B., Tamer, C. E., Sinir, G. O., Suna, S., \& Çopur, O. U. (2016). Impact of different drying parameters on color, $\beta$-carotene, antioxidant activity and minerals of apricot (Prunus armeniaca L.). Food Science and Technology (Campinas), 36(1), 171-178. http:// dx.doi.org/10.1590/1678-457X.0086

Infoclimat. (2013). Aurillac: Associação Infoclimat. Retrieved from http://www.infoclimat.fr/observations-meteo/archives/10/juin/2013/ sidi-bouzid/60748.html?graphiques

Jaradat, N., Jodehb, S., Rinnob, T., Kharoof, M., Zaida, A. N., \& Hannon, M. (2012). Determination the presence of phytomelin in Ecballium elaterium to approve its flok uses. International Journal of Pharmacy \& Pharmaceutical Sciences, 4(2), 233-237. Retrieved from http:// staff.najah.edu/nidal-jaradat/published-research/determinationpresence-phytomelin-ecballium-elaterium-approve-its-f

Judprasong, K., Charoenkiatkul, S., Thiyajai, P., \& Sukprasansap, M. (2013). Nutrients and bioactive compounds of Thai indigenous fruits. Food Chemistry, 140(3), 507-512. http://dx.doi.org/10.1016/j. foodchem.2013.01.057. PMid:23601399.

Kadri, A., Gharsallah, N., Damak, M., \& Gdoura, R. (2011). Chemical composition and in vitro antioxidant properties of essential oil of Ricinus communis L. Journal of Medicinal Plants Research, 5(8), 1466-1470. Retrieved from http://www.academicjournals.org/JMPR

Knittel, J. J., \& Zavod, R. M. (2008). Drug design and relationship of functional groups to pharmacologic activity. In T. L. Lemke \& D. A. Williams (Eds.), Foye's principles of medicinal chemistry (6th ed., pp. 26-53). New York: Lippincott Williams \& Wilkins.

Konczak, I., \& Roulle, P. (2011). Nutritional properties of commercially grown native Australian fruits: lipophilic antioxidants and minerals. Food Research International, 44(7), 2339-2344. http://dx.doi. org/10.1016/j.foodres.2011.02.023.

Kondakova, V., Tsvetkov, I., Batchvarova, R., Badjakov, I., Dzhambazova, T., \& Slavov, S. (2009). Phenol compounds-qualitative index in small fruits. Biotechnology, Biotechnological Equipment, 23(4), 1444-1448. http://dx.doi.org/10.2478/V10133-009-0024-4.

Leja, M., Mareczek, G., Wyzgolik, G., Klepacz-Baniak, J., \& Czekonska, K. (2007). Antioxidative properties of bee pollen in selected plant species. Food Chemistry, 100(1), 237-240. http://dx.doi.org/10.1016/j. foodchem.2005.09.047.

Leong, L. P., \& Shui, G. (2002). An investigation of antioxidant capacity of fruits in Singapore markets. Food Chemistry, 76(1), 69-75. http:// dx.doi.org/10.1016/S0308-8146(01)00251-5.

Li, H. B., Cheng, K. W., Wong, C. C., Fan, K. W., Chen, F., \& Jiang, Y. (2007). Evaluation of antioxidant capacity and total phenolic content of different fractions of selected microalgae. Food Chemistry, 102(3), 771-776. http://dx.doi.org/10.1016/j.foodchem.2006.06.022.

Li, H. B., Wong, C. C., Cheng, K. W., \& Chen, F. (2008). Antioxidant properties in vitro and total phenolic contents in methanol extracts from medicinal plants. LWT -. Food Science and Technology (Campinas.), 41(3), 385-390. http://dx.doi.org/10.1016/j.lwt.2007.03.011.

Lu, X., Wang, J., Al-Qadiri, M. H., Ross, F. C., Powers, R. J., Tang, J., \& Rasco, A. B. (2011). Determination of total phenolic content and antioxidant capacity of onion (Allium cepa) and shallot (Allium 
oschaninii) using infrared spectroscopy. Food Chemistry, 129(2), 637-644. http://dx.doi.org/10.1016/j.foodchem.2011.04.105.

Lukaski, C. H. (2004). Vitamin and mineral status: effects on physical performance. Nutrition (Burbank, Los Angeles County, Calif.), 20(7-8), 632-644. http://dx.doi.org/10.1016/j.nut.2004.04.001. PMid:15212745.

Luo, H. Y., Wang, B., Yu, C. G., Qu, Y. L., \& Su, C. L. (2010). Evaluation of antioxidant activities of five selected brown seaweeds from China. Journal of Medicinal Plants Research, 4(18), 2557-2565. Retrieved from http://www.academicjournals.org/JMPR

Madrau, M. A., Pisicopo, A., Sanguinetti, A. M., Del Caro, A., Poiana, M., Romeo, F. V., \& Piga, A. (2009). Effect of drying temperature on polyphenolic content and antioxidant activity of apricots. European Food Research and Technology, 228, 441-448. http://dx.doi. org/10.1007/s00217-008-0951-6

Mahdavi, R., Nikniaz, Z., Rafraf, M., \& Jouyban, A. (2010). Determination and comparison of total polyphenol and vitamin $C$ contents of natural fresh and commercial fruit juices. Pakistan Journal of Nutrition, 9(10), 968-972. http://dx.doi.org/10.3923/pjn.2010.968.972

Mditshwa, A., Fawole, O. A., Al-Said, F., Al-Yahyai, R., \& Opara, U. L. (2013). Phytochemical content, antioxidant capacity and physicochemical properties of pomegranate grown in different microclimates in South Africa. South African Journal of Plant and Soil, 30(2), 81-90. http://dx.doi.org/10.1080/02571862.2013.802033.

Miguel, M. G., Nunes, S., Dandlen, S. A., Cavaco, A. M., \& Antunes, M. D. (2014). Phenols, flavonoids and antioxidant activity of aqueous and methanolic extracts of propolis (Apis mellifera L.) from Algarve, South Portugal. Food Science and Technology (Campinas.), 34(1), 16-23. http://dx.doi.org/10.1590/S0101-20612014000100002.

Morales-De La Peña, M., Salvia-Trujillo, L., Rojas-Grau, M. A., \& Martin-Belloso, O. (2011). Impact of high intensity pulsed electric fields or heat treatments on the fatty acid and mineral profiles of a fruit juice-soymilk beverage during storage. Food Control, 22(12), 1975-1983. http://dx.doi.org/10.1016/j.foodcont.2011.05.015.

Mphahlele, R. R., Stander, M. A., Fawole, O. A., \& Opara, U. L. (2014). Effect of fruit maturity and growing location on the postharvest contents of flavonoids, phenolic acids, vitamin $\mathrm{C}$ and antioxidant activity of pomegranate juice (cv. Wonderful). Scientia Horticulturae, 179, 36-45. http://dx.doi.org/10.1016/j.scienta.2014.09.007.

Nyanga, K. L., Gadaga, H. T., Nout, J. R. M., Smid, J. E., Boekhout, T., \& Zwietering, H. M. (2013). Nutritive value of masau (Ziziphus mauritiana) fruits from Zambezi Valley in Zimbabwe. Food Chemistry, 138(1), 168-172. http://dx.doi.org/10.1016/j.foodchem.2012.10.016. PMid:23265472.

Othman, O. C., Fabian, C., \& Lugwisha, E. (2014). Post harvest physicochemical properties of soursop (Annona muricata L.) fruits of Coast region, Tanzania. Journal of Food and Nutrition Sciences, 2(5), 220-226. http://dx.doi.org/10.11648/j.jfns.20140205.13.
Re, R., Pellegrini, N., Proteggente, A. E., Pannala, A., Yang, M., \& Rice-Evans, C. (1999). Antioxidant activity applying an improved ABTS radical cation decolourization assay. Free Radical Biology \& Medicine, 26(9-10), 1231-1237. http://dx.doi.org/10.1016/S08915849(98)00315-3. PMid:10381194.

Salhab, A. S. (2013). Human exposure to Ecballium elaterium fruit juice: fatal toxicity and possible remedy. Pharmacology \& Pharmacy, 4(05), 447-450. http://dx.doi.org/10.4236/pp.2013.45064.

Sargin, S. A., Akcicek, E., \& Selvi, S. (2013). An ethnobotanical study of medicinal plants used by the local people of Alaşehir (Manisa) in Turkey. Journal of Ethnopharmacology, 150(3), 860-874. http:// dx.doi.org/10.1016/j.jep.2013.09.040. PMid:24126062.

Schulz, H., \& Baranska, M. (2007). Identification and quantification of valuable plant substances by IR and Raman spectroscopy. Vibrational Spectroscopy, 43(1), 13-25. http://dx.doi.org/10.1016/j. vibspec.2006.06.001.

Schvab, M. C., Ferreyra, M. M., Davies, C. V., Stefani, A., Cayetano, M. C., Gerard, L. M., \& Gonzalez, R. F. (2015). Effects of orange winemaking variables on antioxidant activity and bioactive compounds. Food Science and Technology (Campinas.), 35(3), 407-413. http://dx.doi. org/10.1590/1678-457X.6571.

Skotti, E., Anastasaki, E., Kanellou, G., Polissiou, M., \& Tarantilis, P. A. (2014). Total phenolic content, antioxidant activity and toxicity of aqueous extracts from selected Greek medicinal and aromatic plants. Industrial Crops and Products, 53, 46-54. http://dx.doi. org/10.1016/j.indcrop.2013.12.013.

Suárez-Jiménez, G. M., Robles-Sánches, R. M., Yépiz-Plascencia, G., Burgos-Hernández, A., \& Ezquerra-Brauer, J. M. (2015). In vitro antioxidant, antimutagenic and antiproliferative activities of collagen hydrolysates of jumbo squid (Dosidicus gigas) byproducts. Food Science and Technology (Campinas.), 35(3), 421-427. http://dx.doi. org/10.1590/1678-457X.6658.

Toker, G., Memisoglu, M., Toker, M. C., \& Yesilada, E. (2003). Callus formation and cucurbitacin B accumulation in Ecballium elaterium callus cultures. Fitoterapia, 74(7-8), 618-623. http://dx.doi.org/10.1016/ S0367-326X(03)00165-5. PMid:14630164.

Wang, S. Y., \& Zheng, W. (2001). Effect of plant growth temperature on antioxidant capacity in strawberry. Journal of Agricultural and Food Chemistry, 49(10), 4977-4982. http://dx.doi.org/10.1021/jf0106244

Zakaria, N. A., Ibrahim, D., Sulaiman, S. F., \& Supardy, A. (2011). Assessment of antioxidant activity, total phenolic content and invitro toxicity of Malaysian red seaweed, Acanthophora spicifera. Journal of Chemical and Pharmaceutical Research, 3(3), 182-191. Retrieved from http://www.jocpr.com/

Zhao, H., Wang, Q., Sun, Y., Yang, B., Wang, Z., Chai, G., Guan, Y., Zhu, W., Shu, Z., Lei, X., \& Kuang, H. (2014). Purification, characterization and immunomodulatory effects of Plantago depressa polysaccharides. Carbohydrate Polymers, 112, 63-72. http://dx.doi.org/10.1016/j. carbpol.2014.05.069. PMid:25129717. 